Ofosu, G., Dittmann, R., Sarpong, D. and Botchie, D. (2020) Socio-economic and environmental implications of artisanal and small-scale mining (ASM) on agriculture and livelihoods, Environmental Science and Policy 106, April, 210-220. https://doi.org/10.1016/j.envsci.2020.02.005

\title{
Socio-economic and Environmental Implications of Artisanal and Small- scale Mining (ASM) on Agriculture and Livelihoods
}

\begin{abstract}
Artisanal and Small-scale Mining (ASM) activities continue to grow in many resource-endowed countries with ASM-generated revenues serving as a precursor to socio-economic growth especially in mineral-rich rural communities. However, the rapid proliferation of this extractive activity into new frontiers often extends to territories where, traditionally, agricultural activities may already be present. Considering the destructive effects of the ASM life cycle on the environment, concerns have been raised regarding the negative agricultural impacts of ASM. Thus in this paper, we review the Janus-faced nature of ASM as discourses have developed in the burgeoning literature. Our review reveals an emerging narrative suggesting that in some instances ASM and agriculture complement each other with beneficial consequences. Nevertheless, this highly informal type of mining can have deleterious effects on agriculture through three main mechanisms: land degradation and farm invasions, water and mercury pollution, and the Dutch disease phenomenon - the shift of labour from the agriculture sector to the ASM sector. As most of the operations of small-scale mineral extractors take place in rural communities where agriculture is the main source of livelihood, we find the creation of vulnerabilities in the agrarian economy through these mechanisms. Considering the economic importance of the two sectors to livelihoods, stakeholders would need to recast resources policy to ensure the proper accommodation of both sectors especially in the rural economic space.
\end{abstract}

Keywords: Artisanal and small-scale mining, agriculture, livelihoods, environment

\section{Introduction}

Artisanal and Small-scale Mining (ASM) continues to grow in many resource-rich rural communities. Recent estimates underscore this growth: 40.5 million people were directly engaged in ASM in 2017, up from 30 million in 2014, 13 million in 1999 and 6 million in 1993 (IGF, 2017). With particular reference to gold production, the numbers indicate that ASM production in Ghana, for example, has increased substantially from less than 20,000 ounces in 1990 to 1.6 million ounces in 2016 (Owusu et al., 2019). Why is ASM becoming so widespread? Various explanations have been offered, inter alia: its potential to generate extensive distributional benefits (Banchirigah, 2008); failure of Structural Adjustment reforms (Banchirigah, 2006); 'agricultural poverty' (hardship induced by an over dependency on farming for 
survival) (Hilson and Garforth, 2012); and 'customary land tenure practices' (Nyame and Blocher, 2010). Whatever the reasons for the rapid proliferation of ASM, its expansion invariably takes geographical form, often 'overlapping pre-existing land uses' (Mitchell, 2016). In most cases, the mineral-rich lands small-scale mineral extractors seek to exploit for economic gains are contested spaces already used or claimed by other entities with competing economic interests including large-scale mineral operators (Cuba et al., 2014; Patel et al., 2016). These prior claims and uses are also sometimes related to material consumption (e.g. when these areas are sources of water for the inhabitants) (Bebbington and Williams, 2008), and agriculture production (Kitula, 2006). Thus ASM operations increasingly interface with agricultural activities, making the probability for conflict, as well as the potential opportunity for cooperation between their operations ('farming-mining, mining-farming') and operators ('farming-miners, mining-farmers) great (Maconachie and Binns, 2007).

ASM and agriculture share intricate and dynamic, synergistic and antagonistic relationships. They are intricate because they occupy the same geographic space and share and/or compete for the same factor inputs: land, water, labour and capital, and are dynamic because they are influenced by other exogenous factors including commodity prices (ACET, 2017b). Highlighting their synergies, a number of recent articles in development studies journals have examined the complementarities between ASM and agriculture providing evidence which point to revenues from the latter supporting the former and vice versa (Okoh and Hilson, 2011; Hilson and Garforth, 2012; Maconachie, 2011; Cartier and Bürge, 2011; Kamlongera, 2011; Mkodzongi and Spiegel, 2019; Persaud et al., 2017). Further studies have revealed that these two very important economic sectors serve as engines of employment, viable sources of income, for a majority of rural inhabitants in the developing world; (on ASM see Tschakert, 2009; Siegel and Veiga, 2010; Teschner, 2014; Kamlongera, 2011; Banchirigah, 2008) on rural agriculture see (Reardon et al., 2001). In addition, scholars have put forward more general interpretations on the importance of change in the agrarian economy in which ASM is noted as a central feature (Hilson, 2016a, 2016b; Pijpers, 2014).

However, despite bringing a wealth of socio-economic benefits, ASM also has particularly destructive effects on the environment as well as its antagonistic competition with agriculture in relation to the factor inputs. This Janus-faced nature of ASM can be very disturbing. In this regard studies have shown that the symbiosis between ASM and agriculture, in relation to the acquisition and use of the factor inputs, has not always been smooth (Musemwa, 2009). While the competition for space and resources has sometimes led to coexistence and synergies among forms of land use (Maconachie and Binns, 2007; Pijpers, 2014), the strong competition over access to land, between these two rural development drivers, has mostly resulted in resource-use conflicts (Musemwa, 2009). 
ASM as an extractive activity can have negative effects on agriculture through various mechanisms. One key mechanism is land degradation. The negative legacy of ASM - mine pits and excavated soils - can render previously fertile lands unsuitable for crop production thereby reducing the availability of land for agriculture production (Kitula, 2006; Mantey et al., 2016; Ncube-Phiri et al., 2015). In addition, the environmentally destructive effects of ASM such as bush burning and deforestation reduces the availability of grazing areas for livestock (Ncube-Phiri et al., 2015). This can entrench a cycle of poverty in the agrarian economy through loss of farming-generated income and a reduction in food and cash crop and livestock production. Another troubling facet is the asymmetry of the effects of ASMagriculture interactions. Agricultural production pollution problems (see for example Ntiamoah and Afrane, 2008) do not affect the integrity of non-renewable mineral deposits, but the siting of ASM activities close to agricultural productive lands has been observed to reduce crop yields through farm invasions and the destruction of cultivated crops (Boadi et al., 2016; Arthur et al., 2016).

More so, land reclamation projects in mining hotspots, aimed at restoring mining-degraded lands to close to original conditions, to make them suitable for a variety of other important industrial applications including agriculture production, can come at a huge cost to the budget of the national government (Mantey et al., 2016). The Colombian Ministry for Biodiversity, for example, estimated that it would cost about $\$ 10.8$ billion and take anywhere from 25 to 40 years to remedy the environmental devastation caused by the deforestation and contamination of mining sites in Colombia (Kinosian, 2012). Mantey et al. (2016) estimated that a total amount of $\$ 198$ million was needed for the environmental remediation of small-scale affected lands in the Western Region of Ghana alone. In perspective, the Western Region is just one out of eight major regions in Ghana where informal ASM is practised (Bansah et al., 2018).

Equally worryingly, ASM can have negative impacts on agrarian livelihoods through the water pollution mechanism (Obiri et al., 2016; Mujere and Isidro, 2016). This is manifested in instances where ASM activities disrupt river systems, reducing the flow rate of water, thus denying farmers adequate water for more productive agriculture (Ncube-Phiri et al., 2015). Elsewhere, it has been noted that the boom in ASM-related activities correlates with an increase in the use of mercury (Seccatore et al., 2014) and water (Shoko, 2002). This spawns consequential resource-related contestations between ASM operators and agriculture entities, especially where a single water source is used for both mineral processing and irrigation purposes (ACET, 2017b). The mercury amalgamation technique of mineral processing, leading to the discharge of cyanide, mercury and other metal rich tailings into rivers, pollutes and renders aquatic bodies unfit for consumption (Mudyazhezha and Kanhukamwe, 2014; Mol and Ouboter, 2004). 
The resource-use competition between ASM and agriculture also revolves around labour dynamics. The extensive reliance on manual (unskilled) labour in both economic sectors and the higher remuneration available in ASM can lead to a rapid exodus of labour into mining - a Dutch disease mechanism (Hilson and Laing, 2017; Boadi et al., 2016). Although this phenomenon has detrimental consequences on agricultural production (Hilson and Laing, 2017), an empirical perspective to the labour conundrum has demonstrated elsewhere that the 'pull' of labour into ASM has been fuelled by the 'push' of labour out of the agrarian economy as a result of 'agricultural poverty' (Hilson and Garforth, 2012).

Obviously the environmental quagmire associated with ASM, and particularly related to agriculture, is pressing and needs redressing, particularly because productive land is rapidly disappearing throughout the world (Nunez, 2019). This review therefore has two main aims. The first one is to pull together into a single discussion a cross section of the ASM literature that examines the interaction (synergistic and antagonistic) between ASM and agriculture as a central theme. In this sense we build on the works of scholars such as (Okoh and Hilson, 2011; Maconachie and Binns, 2007; Hilson, 2016b) etc and organisations such as (ACET, 2017b). The aim is not to be exhaustive; however, we include more literature and discuss issues not found elsewhere. We shed the light on ASM (and not on agriculture) because of the threat posed to agriculture by ASM, which is largely unregulated (IGF, 2017; Wagner, 2016). The second aim is to summarise the recommendations for policy advanced in the ASM-agriculture literature. In this way, the study seeks to contribute to the analyses of the socio-economic and environmental aspects of ASM.

\section{Methodological approach}

In our effort to highlight emerging themes of the ASM-agriculture complementarities, and provide a detailed overview of ASM activities and its associated environmental degradation problems, we employed a literature synthesis approach as proposed by (Webster and Watson, 2002). We aim to conduct a review and then propose a conceptual model that qualitatively synthesises and extends the existing research in the ASM-agriculture intertwinement.

A literature search was undertaken using the multidisciplinary database Scopus and Google scholar to identify influential papers in this research domain. These databases have broad coverage of the natural resource management and the extractive industry.

Limiting our research to the following key words-'artisanal and small scale mining and livelihoods', agriculture and small scale mining and livelihoods', and 'artisanal and small scale mining and environmental degradation', we were inundated with over 7000 bibliographic items so we adopted a coding process. The results of each search string were assessed and screened in order to check whether a 
particular literature met our pre-determined inclusion criteria. Papers written in English, drawn from published sources and focused on term searches were included in the study. The choice to only include literature published in English was made to reduce the huge literature to a more manageable number (Petticrew and Roberts, 2006).

In order to contextualise the ASM-agriculture dynamics and discussions, no periodization was placed on the search for literature. Methodologically we note that the literature mostly employed the qualitative and ethnographic research methods and was heavily focused on Africa (because of its resource endowment), and Ghana because it is a 'mature mining economy' (Hilson, 2016b). Although a broad selection of the peer-reviewed literature was reviewed covering diverse aspects of ASM, we particularly focus on 16 peer-reviewed articles that deal particularly with the ASM-agriculture interface concerning livelihoods and environmental degradation. We briefly outline the recommendations of these works in line with the second aim of this study. For the sake of the analysis, the works are categorised as 'positive' if the study generally considers the ASM-agriculture intertwinement as complementary. A study is considered as 'negative' if it highlights the environmental degradation problems of ASM, and generally considers ASM as having an environmentally deleterious effect on agriculture. Where recommendations are many and diverse, we focus on the ones particularly related to the improvement of the farming-mining relationship.

\section{[Insert table 1 about here]}

\section{Agriculture}

To begin, it is appropriate to clarify that the term "agriculture" refers to 'the art, science and practice of farming - cultivating the soil, producing crops, and raising livestock - and in varying degrees the preparation and marketing of the resulting products' (as defined in the Oxford Dictionary). Although the share of the world population engaged in agriculture is declining due to industrialisation and urbanisation, the sector still retains a key role in most economies especially in Africa (ACET, 2017a). A World Bank 2016 analyses found that $65 \%$ of poor working adults made a living through agriculture (The World Bank, 2019).

In Africa, the agricultural sector plays an even bigger role in employment generation. Its share in total employment reaches a high of more than 70\% in Rwanda, Madagascar, Guinea, Ethiopia and Uganda (ACET, 2017a). Notwithstanding the economic importance of agriculture in most African economies, however, food production is still low due to the low use of technology; most farms are small - the average size in many countries is below 3 hectares and a majority of farms are under 2 hectares; most smallholder farmers are essentially subsistence farmers (ACET, 2017a). The smallholder status means that the sector is chiefly organised as a family business with almost all agronomic activities such as weeding, sowing and 
harvesting undertaken by family labour; the equipment for farming operations are rudimentary, just like most ASM operations, and require a youthful labour force (ACET, 2017b). But as the youth is moving into ASM (Okoh and Hilson, 2011), the agricultural sector is increasingly becoming home to an aging workforce, leading to low productivity. The low productivity has also been associated with inadequate supply of agrochemicals and other inputs and low remuneration of contracted labour (ACET, 2017b). In addition, the change in climatic conditions continues to have profound effects on plants and animals threatening the food security of subsistence-oriented communities (Savo et al., 2016) .

Considering the structural and technical difficulties that already afflict agriculture, it becomes imperative to study the role that ASM, another low-tech activity that usually operates in close proximity to agriculture, plays in the agricultural production dynamics. How is this geographical neighbour engineering the agricultural sector to make it viable, or how is it entrenching the already existing problems? We turn to the ASM literature for these answers.

\section{Artisanal and Small-scale Mining}

ASM is generally characterised as a low-tech, low capital, and labour-intensive resource extraction activity of relative high value alluvial minerals such as gold and diamonds; it is also described as a poverty driven activity with low-entry barriers and minimum mechanisation (Banchirigah and Hilson, 2010; MMSD, 2002, p.315). The miners are mostly local groups or individual entrepreneurs using primary technology such as wheel barrows, pick-axes and shovels. Although ASM is associated with minimum mechanisation, in some countries, e.g. Ghana (Bach, 2014), Philippines (Verbrugge, 2014), Guyana (Clifford, 2011), and Brazil (Graulau, 2001) the phenomenon has been the intense mechanisation - the use of sophisticated technology such as excavators, dredgers etc - of the small-scale mineral industry due to the influx of foreign capital, increasingly from China (Burrows and Bird, 2017; Hilson et al., 2014; Crawford and Botchwey, 2017). These country cases are the few exceptions though; in the general case ASM qualifies as a low-technology enterprise with a high level of informality.

\section{ASM as a poverty fighter}

ASM as a resource extraction activity can be a springboard to poverty alleviation. This is because its considerable socio-economic benefits are not only restricted to employment generation, but also encompass the importance of revenues from resource extraction, at least at the macroeconomic level, as postulated by Sachs (2007). Firstly, in principle, revenues accrued from resource extraction can boost real living standards by providing finances for higher levels of private and public consumption. Secondly, since resource revenues typically accrue largely to the public sector, and indeed to the public budget, it can remove a huge 
barrier to development: the lack of fiscal resources needed to finance core public goods (Sachs, 2007). This has typically been the case in many resource-rich countries which are known to receive revenues from resource extraction as a component of their GDP. However, studies have often shown that the economic performance of many resource-endowed countries has often fallen far short of potential - the resource curse (Auty, 1993; Sachs and Warner, 1995), discussions of which are largely beyond the remit of this study.

ASM, despite its low productivity has been a valuable source of minerals and metals; it accounts for about $20 \%$ of the global gold supply, $80 \%$ of the global sapphire supply and $20 \%$ of the global diamond supply; the sector is also a major producer of minerals indispensable for manufacturing popular electronic products such as laptops and phones, for example, $26 \%$ of global tantalum production and $25 \%$ of tin come from ASM (IGF, 2017). As noted by Ross $(2004,2003)$, resources that are usually extracted through labourintensive processes, such as alluvial diamonds and gold, tend to produce higher economic benefits to local economies in poor regions. This situation typifies the case in most alluvial-mineral-rich economies. The ASM sector, for years, has served as a motor of especially low-skill employment en masse in countries such as Ghana (Banchirigah, 2008), Mali (Teschner, 2014), Malawi (Kamlongera, 2011), The Democratic Republic of the Congo (Geenen, 2012), India (Ghose and Roy, 2007), Indonesia (Fisher et al., 2019), Cameroon (Bakia, 2014), Mozambique (Dondeyne and Ndunguru, 2014), Senegal (Persaud et al., 2017) etc. Also the ASM sector 'can act as a platform for wealth creation, and as a stepping stone towards social mobility' (Verbrugge, 2016). Revenues from the ASM sector have provided 'start up' capital for the establishment of other small-scale enterprises, financed education, and paid medical costs for many miners especially women (Maconachie, 2011, pp.1064-1066). Funds from ASM have also lubricated smallholder agricultural activities; we discuss this in detail in the following section.

The ASM sector is not only imbued with economic benefits. Aizawa (2016) provides evidence from Tanzania to show that the sector can act as an 'informal safety net' where miners capitalise on the enormous human relationships in the sector to build a kind of social capital which can be an important asset in times of economic hardships (see also Geenen, 2011) for similar arguments concerning the local gold trade networks in the DRC. The low-entry barriers into ASM also mean the sector provides other benefits, as noted elsewhere:

Those attracted to small-scale mining generally enter without specialized mining skills. In effect, a miner's first work site is an apprenticeship where he earns as he learns. (Bryceson and Jønsson, 2010, p.380). 
Although earnings in the ASM sector are considerably higher than the average income of comparable agricultural regions (Walsh, 2003; Ingram et al., 2011), it has been reported that small-scale mineral operators are unable to translate their incomes into savings and investments - two essential economic ingredients required for the sustained improvement of livelihoods (Walsh, 2003; Werthmann, 2003). Walsh (2003) refers to transient high earnings as "hot money" that fuels 'daring consumption' in the mining towns in Madagascar, although Mkodzongi and Spiegel (2019) provide a contrasting perspective with evidence that ASM-generated funds are employed for more productive purposes. The 'hot money' economic malaise has also been attributed to the mercury amalgamation processes for mineral extraction (Hilson and Pardie, 2006) and the high cost of living in ASM communities (Labonne, 2014).

The increasing mechanisation of ASM operations warrants attention. While mechanisation may be increasing the production levels of alluvial minerals, the practice is not without shortcomings. Increased mechanisation of ASM (where capital is substituting labour, attracting foreign ownership), may be mirroring LSM industrial practices of 'enclavity' - a mode of resource extraction with little employment generation and distribution effects (see Langston et al., 2015). This is beginning to raise questions about the long-term 'engine of employment' potential of ASM (ACET, 2017b). We note that these discussions require further empirical enquiry.

\section{ASM and agriculture: friends?}

Scholarship on ASM-agriculture linkages usually look at one of two issues: 1) ASM and agriculture as complementary economic activities 2) ASM as a competing economic activity at odds with agriculture through crop destruction, water pollution and land degradation. Whereas narratives in the second category have long been prominent in scholarly works, in reports by international organisations and particularly in the media, those in the first category seem to have gained prominence in scholarly articles in recent times. This strand of literature casts the spotlight on the mining-farming complementarities that are shaping rural labour trajectories. The literature generally argues that agriculture has become an unviable livelihood option particularly due to structural adjustment and climate change and that for many people, especially in Africa, ASM has become an important element of their livelihood portfolios (Banchirigah, 2008). We shall return later to these discussions concerning ASM as a livelihood diversification or complementary activity in relation to agriculture. For now, we just mention that other works have generally examined livelihood diversification in rural contexts, sometimes in relation to agriculture, but without the spotlight on ASM. We examine a few of them as a way of providing a background context to the issue. 


\section{Livelihood diversification in rural context}

Ellis (1998) defines livelihood diversification as the process by which rural families construct a diverse portfolio of activities and social support capabilities in their struggle for survival and in order to improve their standard of living. The diverse portfolios usually consist of livelihood activities outside the realm of the farm sector (soil cultivation and livestock rearing), and include nonfarm activities such as services, construction, mining, commerce etc (Lay et al., 2008). Contrasting with the conventional wisdom that most rural households, especially in sub-Saharan Africa, subsist on farming activities, Reardon et al (1994) point out that the nonfarm sector provides an important share of household income (see also Bryceson, 2002; Ellis, 2006). As explained by Barrett et al. (2001), in many rural communities in Africa, 'diversification is the norm; very few people collect all their income from any one source, hold all their wealth in the form of any single asset, or use their assets in just one activity' (p.315). According to Haggblade et al. (2010) nonfarm earnings account for $35-50 \%$ of rural household income across the developing world.

Underpinning most narratives on livelihood diversification is the general issue that structural adjustment programmes and shrinking government budgets, which have brought large cuts in formal credit and input supply programmes, and in subsidies for fertilizer (Reardon et al., 1994) have engendered 'de-agrarianisation' - a reorientation of livelihoods away from the agrarian sector, and subsequent unemployment (Banchirigah and Hilson, 2010). Although some small-scale mineral extractors found in mining camps are 'career miners' (Bryceson and Jønsson, 2010), de-agrarianisation has however involved the push of many unemployed youth into ASM in many resource-rich regions (Banchirigah and Hilson, 2010; Banchirigah, 2006). Hilson and Potter (2005) studying the effects of structural adjustment policies on employment in Ghana found that "a declining standard of living has not only attracted recent school graduates but has also persuaded a wide range of former professionals, semi-skilled labourers, and retrenched large-scale mine workers to relocate to the many rural reaches of the country where artisanal gold mining can be readily carried out" (p.113). Livelihood diversification into ASM is also generally pursued with the intention of miners to branch out into the nonfarm economy because they believe they can earn more revenues from doing so (Hilson and Garforth, 2012). To Pijpers (2014), the ASM economy sometimes represents an 'economy of dreams' for many miners. Dreams of a better life, schooling for miner's children, a car, going to another place (such as Europe) or building a house; dreams that are difficult to have when, for example, one engages in subsistence farming (Pijpers, 2014). As can be gleaned from table 1, a sizable literature finds a positive relationship between ASM and agriculture with a section of the master narrative from these studies pointing to qualitative evidence that many families turn to ASM to supplement their farming earnings and invest in farming and farm inputs (Maconachie and Binns, 2007; Okoh and 
Hilson, 2011). It is to this emerging narrative that we now turn, focussing particularly on the qualitative responses that undergird the evidence.

\section{ASM and agriculture: the evidence of friendship}

Hilson and Garforth (2012) find that diminishing returns from agriculture have provided the incentive for farm families to branch out into ASM. However while farming may no longer be the primary economic activity, its importance has by no means diminished especially in the context of generating food to satisfy household consumption demands. The study further shows that revenues from ASM reactivate farming as exemplified by one of the responses from a 'farmer-miner':

I am mining full-time to find monies for fertilizers...(My) full-time work is farming but (I) come on to mine site to find monies for fertilizers. (I) also use money to buy insecticides. (p.457).

These findings substantiate other findings of studies undertaken in Ghana. The same authors find another 'farmer-miner' explaining that:

we get money from mining and we use it to buy chemicals for farming (Hilson and Garforth, 2013, p.360)

The findings also echo those of Okoh and Hilson (2011) as they present complementary analysis from a similar research conducted in the Brong Ahafo Region of Ghana, an examplar site of one the largest ASM workforces in sub-Saharan Africa. Here, a 'farmer-miner' narration of his experience qualifies as perspicacious acceptance of ASM as a force for good:

I have cleared my farmland awaiting the rains to set in so that I will go back and cultivate the crops. I have been at this mining site since the beginning of the dry season, and I am happy to tell you that I have made some money to supplement my income from farming. Even the money I used in hiring labour to clear my farmland was made here in mining... (p.1111).

In other parts of the African continent, similar findings have been unearthed. In Malawi, Kamlongera (2011) makes a case for promoting ASM. The author critically assesses the socio-economic impact the ASM sector is having in rural communities, where it now flourishes alongside smallholder agriculture, and examined the linkages between both economic activities, sharing insights from miner-farmers on the importance of both sectors to their livelihoods: 
As much as we are dependent on mining, cultivating maize or other food crops for self-sufficiency is important... (p.1136).

In Sierra Leone, field research conducted by Maconachie and Binns (2007) in and around Kayima illustrates the diversification of livelihoods in the region with the work showing that there have long been strong linkages between the farming and artisanal diamond mining sectors. The work particularly demonstrates how the diamond mining and rice farming economies intertwine with a labour allocation cycle i.e. mining being undertaken predominantly in the dry season when river levels have subsided and farming being carried out mainly during the rainy season (see also Hilson, 2016a). Similarly, analysing the post-war rural economy in Sierra Leone, Maconachie (2011) finds, on the one hand, that income derived from ASM provides valuable investment funds for reinvigorating the agrarian institutions (reagrarianisation) and social networks that are important to the post-war rural economy. However, on the other hand, and in contrast to the 'agricultural poverty' evidence, diminishing returns from diamond mining operations coupled with the institutional and policy challenges of the mining sector was responsible for persuading some individuals to exit ASM and encouraging them to re-orientate their livelihoods more exclusively around farming.

Mkodzongi and Spiegel (2019) studying the social dynamics around the dramatic increase in ASM after the land reforms in Zimbabwe find evidence in support of the 'agricultural poverty' syndrome which had driven most miners to seek livelihoods in ASM. Evidence is also deduced in support of the 'farmingmining' phenomenon as recounted by one 'farmer-miner':

I do mining the whole year through and I also do the farming, mining here and farming there, that is what I do (p.2155).

Although enough qualitative evidence is provided in support of the ASM-agriculture complementarities, we posit that the evidence should be interpreted with a bit of caution. This is because ASM booms trigger major population influxes (Bryceson and Jønsson, 2010). Supporting the migratory features of ASM as discussed in the preceding study, for example, results from the pilot survey by Okoh and Hilson (2011) reveal that $70 \%$ of the miners had come from distant towns and communities. The migration figure was much higher (over 92\%) in Northern Ghana (Hilson et al., 2013, p.126). Thus the interviewees who respond favourably to the 'good' relationship between ASM and agriculture may not live and have their farm lands in and around the mining sites (we refer to them as 'lucky migrants'). They may even not have come from mineral-rich areas. Thus it is convenient for them to travel to distant mining 
sites to engage in the activity (especially during the dry season) and go back to find their farms intact (during the wet season). With studies showing the high informality rate and the consequent environmental degradation associated with ASM, those who reside in the mining communities (we tag them as 'unlucky locals') who mostly suffer from farm invasions, and polluted water bodies may view the complementarities differently as exemplified by the views of a female farmer in Ghana:

I am a farmer and have farmed for so many years but the presence of ASM activities in the town,

Bondaye has destroyed many of my farmlands, especially my sugarcane farm which provided me a source of income to help send my children to school. I believe ASM has greatly destroyed many farmers' household income and is still having negative effects on us. (Arthur et al., 2016, p.11)

The ASM-agriculture complementarities may therefore be only partly true for non-mineral-rich areas where smallholder farmers do not have to deal with competing ASM interests.

\section{Towards a conceptual model for the ASM-agriculture complementarities}

Our review of the burgeoning literature on ASM-agriculture interaction suggests three fundamental outcomes in resource-endowed countries. We employ a heuristic framework (see figure) to delineate the linkages and complementarities between ASM and agriculture. First, the revenues from the ASM economy supplement agriculture income and vice versa. Second, the earnings from ASM are used to purchase important farm supplies to support agriculture. Third, the earnings and food from the agrarian sector are used to support ASM. In this regard, we argue that the 'new' earnings and food that become available because of the ASM revolution soon become vulnerable to the same process that sets them free, as the mining areas start to serve as catalyst of ready markets for agricultural produce. In practice, the activities in the two sectors are largely influenced by seasons (wet or dry season).

\section{[Insert figure 1 about here]}

In the next section, we present a qualitative synthesis of past research to develop our thesis on the potential negative outcomes of ASM-agriculture interrelationship in practice.

\section{Mining and agriculture: The collision course}

As indicated earlier, mining (small-scale and large-scale) and agriculture both demand a significant amount of factor inputs - land, labour, water and capital in order to operate. Meanwhile, both activities are often located in the same geographical space (Cuba et al., 2014), sometimes on concessions - referred to as 'hot 
spots': contested spaces characterised by accelerated changes and an increased density of activities and claims where power is deployed in various forms (Pijpers, 2014, p.35). Considerable overlap between mining and agriculture (Cuba et al., 2014), and a potential for conflict through the competition for the key inputs is thus often created (Aragon and Rud, 2012). We found some studies that have expended considerable effort and time to examining these issues and, for the purposes of our study, they merit attention. Both Ghana and Peru have large agricultural economies and extensive extractive sectors and are therefore appropriate study sites for a comparative analysis of 'geographies of conflict' (Bebbington et al., 2014). Therefore, Cuba et al. (2014) focus on the these two countries and employing geographies of extractive industry concessions indicators visualizes spatial overlaps between extractive concessions and river basins, agricultural land use, and protected areas in Peru and Ghana. The study finds that large tracts of agricultural land use in both countries are located within areas that are subject to mineral or hydrocarbon concessions (38\% in Peru, 39\% in Ghana). Although the findings do not particularly indicate conflict situations between the actors of these sectors due to the overlap, it does help to visualize the geographies of uncertainty and risk that the expansion of extractive industry creates for populations dependent on agriculture, land, water and other resources in areas affected by concessions (Cuba et al., 2014). In a similar study in Ghana but with a focus on land degradation and loss of farmland, Schueler et al (2011) using a time series of maps created from satellite data reveal that $45 \%$ of concession areas had experienced substantial loss of farmland, and 58\% had experienced deforestation due to surface mining practices in the Wassa West District.

These concession and pollution issues caused by mining can lead to greater agitations. Such was the case in the US, for example, where a long judicial combat was encountered when farmers with lands downstream from the Bunker Hill Smelter strongly complained about how pollutants such as fumes and lead debris emanating from the operations of the smelter posed a threat to their property and harmed their livestock (Aiken, 1994). Although these studies focus primarily on large-or-medium-scale mining, they provide useful insights into the collision course between agricultural and mining interests and therefore provide a firm base to analyse the antagonistic relationship between small-scale mining and agriculture. However, before examining this antagony, in this case the destructive effects of ASM on agriculture, it is important to note that ASM, unlike LSM, is environmentally destructive because it is largely informal ie most of the operators operate without requisite licences. Against this background, the study now shifts to the examination of ASM's informality in order to contextualise the environmental problems associated with the sector. 


\section{[Insert figure 2 about here]}

\section{ASM informality - the crux of the environmental problem}

Generally, the discovery, extraction and processing of mineral resources has been widely regarded as one of the most environmentally disruptive activities undertaken by humankind (Peck and Sinding, 2003). To Weber-Fahr (2002), the mining industry is an environmental 'footprint' industry. Studies have indeed shown that the environmental performance of the large-scale mining industry has sometimes bordered on the abysmal (Kumah, 2006; Lindahl, 2014). However, the formalisation and legal regularisation of the largescale mining industry in many countries has largely ensured agreement over the remediation of environmental pollution issues (Jacka, 2018, p.66). In contrast, the clandestine and illegal nature of ASM in most developing countries has engendered consequential environmental catastrophes. Although minerals and mining laws in resource-rich countries require small-scale mineral extractors to be licensed and their operations regulated, the majority of small-scale miners, worldwide, operate informally without the security of a licence (McQuilken and Hilson, 2016; Veiga and Marshall, 2019) due, in part, to the fragmented nature of the small-scale mining industry. In Ghana, illegal mining, prior to its ban in 2017, was so horribly widespread. Teschner (2012) perceptively describes the problem at hand:

In fact illegal mining is so public that the casual observer may not believe it could possibly be illegal (p.312).

The situation is no different in other mineral-rich countries (Geenen, 2012; Siwale and Siwale, 2017). The ASM explosion and environmental problems have been largely precipitated by 'stifling regulatory frameworks' (Hilson, 2016b; Banchirigah, 2006) and the lack of enforcement of the mining regulations, and weaknesses in the legislative framework. Factors such as the long and cumbersome, corruption-ridden process of mining registration and the exorbitant mining license fees discourage many miners from registering their operations (Afriyie et al., 2016; Aryee et al., 2003; Chipangura, 2019; Salo et al., 2016; Hilson and Van Bockstael, 2011). Even in Niger (Hilson et al., 2019) and Tanzania (Mwakaje, 2012) where licensing fees are relatively lower than in other countries in sub-Saharan Africa, the registration process remains procedurally complex. In some instances, for example, in Liberia, Van Bockstael (2014) explains that the high formal registration fees had resulted in a 'locally grounded formalisation process' i.e. informal taxation arrangements between miners and local government officials, with beneficent economic results.

The main institutions with direct supervisory and oversight responsibilities over the mining sector in resource-rich countries are usually ill-equipped, hence lack the needed capacity to ensure the effective regulation and supervision of the small-scale mining sector (O'Faircheallaigh and Corbett, 2016; Siwale and 
Siwale, 2017; Veiga and Marshall, 2019). Moreover, the defined roles of the various mining regulatory institutions usually constitute statutory roles with no effective cross-sectoral linkages among the institutions (Akabzaa and Darimani, 2001; O'Faircheallaigh and Corbett, 2016; Veiga and Marshall, 2019). In some cases, the regulatory personnel simply fail to enforce the law (Teschner, 2012; Chipangura, 2019). These factors create a regulatory lacuna and culminate in the explosion of illegal small-scale mining activities across countries. As in many parts of the world where mining activities are carried out, such weak and ineffective regulatory dispositions leave the natural environment at the mercy of polluters, a sad reality in most ASM countries.

The IGF (2017) estimates that about 70-80\% of ASM operations globally are informal. Statistics on the illegal small-scale mining in Latin America stand out: about $77 \%$ of gold mined in Ecuador, $80 \%$ of Colombian gold and 80-90\% of gold mined in Venezuela is illegally produced (Wagner, 2016).

The takeaway point here is that ASM, being an extractive activity, inevitably spawns environmental problems. However these environmental problems are exacerbated by the informal and itinerant nature of most ASM operations which consequently speed environmental destruction in many alluvial-mineral-rich countries, leaving many rural farmlands and other economic activities in shambles. In the paragraphs that follow, we explore the mechanisms through which ASM can negatively impact agriculture.

\section{ASM and agriculture: foes?}

\section{Land use and degradation}

Perhaps no single industry has precipitated more disputes over land use than mining (Hilson, 2002a, p.65)

The miner-farmer dispute over access to distribution and control over natural resources and space is well grounded in history; it was at the base of many inter-tribal and inter-racial struggles in colonial Zimbabwe (Musemwa, 2009). Central to this dispute is the acquisition and use of land, and degradation associated with mining practices (Tom-Dery et al., 2012). In Ghana, it has also been at the heart of the mining-farming conundrum with increased mining resulting in the destruction of farmlands and reduction in agricultural productivity. This is well illustrated by Boadi et al. (2016); their study established that in 5 years illegal mining had degraded $4.4 \%$ of the total area of the Offin Shelter belt. Consequently most farmlands bordering the forest belt had been destroyed (Boadi et al., 2016). This study, though very revealing, is not unique. Environmentally destructive effects of ASM of this nature have occurred throughout other regions in Ghana. A study by Boateng et al. (2014) in the Atiwa district of Ghana reveals major scales of desertification and land degradation. The study finds that on the average, about 50 hectares of land had 
been taken from cocoa farmers by illegal mining operators. Bach (2014) shows that an estimated 30-50\% of the farmland in the Amansie West district was lost due to the 'Chinese galamsey'. As recounted by an interviewee:

Until the advent of these Chinese, the galamsey activities wasn't large scale. Because the miners were using simple instruments. They were not using bulldozers, excavators. So it was the Chinese who introduces this idea of this. So, let's say, in about a week, if a Chinese miner settles here for, in about a week, the kind of devastating effect that will occur. Like, they clear everything on site. If they have the belief that gold is located here, it's cleared on site. Meaning, even if it is vegetation it's cleared, even if it's forest, its cleared. And water bodies, they don't care. So, they destroy everything. Everything natural or artificial, when it's gold located there, the Chinese mine there. And because they use these excavators, they can cause a lot of trouble. (Bach, 2014, p.48).

Another area of the ASM-agriculture contestation is the negative land legacy of mining abandoned pits, degraded lands - which render land unfit for agricultural purposes. Here, Mantey et al (2016) provide useful insights through their study focussing on the closure and reclamation of degraded ASM (galamsey) sites, with the objective of returning the sites to a suitable state which would support premining land use activities such as small-scale agriculture, hunting, and artisanal forestry. In the Western Region of Ghana (a hotspot for ASM and agriculture), the statistics are telling: about 1,845 abandoned ASM sites and mine pits could be found in approximately $50 \%$ of the districts with the three most impacted districts, in terms of land-take or operational footprint, being the Amenfi East (58.3\%), Tarkwa Nsuaem (17.5\%) and Prestea Huni Valley (8.5\%) (see also Owusu-Nimo et al., 2018).

In the Geita mining district in Tanzania, Kitula (2006) also found numerous abandoned mining sites and pits in the mining-farming communities, with the effect on agriculture and livelihoods being that these 'mine pits not only make land unsuitable for agricultural activities following closure but also adversely impact livestock and wildfire resources, which, in turn, affects locals who depend on power and animal manure' (Kitula, 2006, p.410). To Kitula (2006, p.410) the prevalence of the abandoned mine pits may partly explain why he found fewer respondents $(2.7 \%)$ undertaking agriculture and livestockmanagement tasks, compared to the $10.8 \%$ in surveyed non-mining areas. However, as previously discussed, the observed low-agriculture phenomenon in ASM areas could also be attributed to the 'agricultural poverty' syndrome (Hilson and Garforth, 2012) and the 'economy of dreams' phenomenon (Pijpers, 2014) ie in mineral-rich areas, labour would choose ASM over agriculture due to the high earnings. Here, negative complexities on livelihoods in the ASM-agriculture intertwinement can emerge. While 'agricultural poverty' provides impetus for increased activities in ASM, the rise in ASM activities render 
previously fertile agricultural lands unfit for purpose, thereby locking labour into ASM, leading to a vicious cycle of agriculture decline even though workers might want to return to agriculture in the 'bust' phases of the ASM cycle. In other parts of mineral-rich territories, ASM-degraded lands and abandoned pits are common: in the Amazon region (Wagner, 2016; Peterson and Heemskerk, 2001), Zimbabwe (Ncube-Phiri et al., 2015) and the Great Lakes Region of Central Africa (Macháček, 2019).

\subsection{Water and mercury pollution}

River bodies serve as sources of water for domestic purposes in most rural communities. They also serve as sources for farmland irrigation and food cropping. Thus the pollution of water resources (see for example Mujere and Isidro, 2016) poses serious challenges for agricultural production, more so in Africa, for example, where only about $5.4 \%$ of agriculture is irrigated (ACET, 2017a). Thus the boom in ASM which invariably leads to the discharge of cyanide, mercury and other metal tailing into rivers (Shoko, 2002) in farming-mining communities raises questions about the long term sustainability of the ASM-agriculture complementarities. Irrigation of agricultural lands with the acidic water contaminates food crops and renders the soil infertile (Lin et al., 2005).

Relatedly, various studies have indicated that mercury pollution is rampant in most small-scale mining communities with Colombia having the unenviable reputation as the country with the highest level of mercury contamination in the world due to unregulated mining (Wagner, 2016; Cordy et al., 2011). The Carnegie Amazon Mercury Project found that artisanal gold extractors dump in excess of 30 tons of mercury in water bodies in the Amazon region every year, generating levels as high as 34 times the safe limit for women of childbearing age (Wagner, 2016). In Peru, government estimates revealed that mercury pollution had affected 48,000 people across 85,301 square kilometres in the Madre de Dios region (Fraser, 2016). These findings are in line with other studies affirming the use of mercury in small-scale mineral processing and its serious health effects on the miners and other members of the mining community (Dai et al., 2003; Hilson, 2002c; Lacerda and Marins, 1997; Malm, 1998; Ogola et al., 2002; Pfeiffer et al., 1993; Van Straaten, 2000; Serfor-Armah et al., 2005; Dartey et al., 2013). Of significance to the discussions in this paper, and of concern to agriculture is that the harmful effects of mercury do not only deprive farming communities of safe water for irrigation and other domestic purposes, but also endanger the life of 'farming labour' which can have both short and long term impacts on labour-hours for farming and production levels.

\section{ASM and labour}


Another troubling aspect of the ASM-agriculture interrelationship is what manifests as the resource curse (see Hilson and Laing, 2017). This 'resource curse', phrased by Auty in 1993, describes the counter-intuitive link between a country's natural resource endowment and its economic, social, and political functions. Particularly, proponents of this curse observe that natural resource-endowed countries tend to have slower economic growth than their non-resource rich counterparts (Ross, 2015), with the 'Dutch disease' (Corden and Neary, 1982; Corden, 1984) as one of the causal mechanisms. Among other things, this Dutch disease occurs when natural resource booms increase the domestic income and the demand for inputs such as labour and other materials. The prices of these inputs thus rise in the domestic market (Badeeb et al., 2017). As a result, the production costs of other traditional sectors such as agriculture increase, contracting these sectors (Badeeb et al., 2017). This is what Humphreys et al (2007) refer to as the 'pull effect', and, in the case of ASM, what Hilson and Laing (2017) refer to as 'gold mining-induced resource movement effect'. This 'effect' partly explains the commandeering of labour by ASM in relation to agriculture. Two studies are of

particular note here. Hilson and Laing (2017) find that in Guyana the booming ASM sectors had heavily drawn labour away from the agriculture sector and stifled the growth of other sectors, in the process, making the country's economy one dimensional. Elsewhere Boadi et al. (2016) show the 'pull' effect when after the rapid expansion of illegal mining, farming among respondents reduced from $90 \%$ to $76 \%$.

\section{Discussion and conclusion}

The review has sought to look at the rapid proliferation of ASM in the context of emerging discourse surrounding the sector's complementarities with agriculture, and the ever-growing problems of its environmental footprints. As the literature has shown, ASM can indeed be a 'blessing' by serving as an avenue of employment for millions of people (Hilson, 2016b, 2002b; Kamlongera, 2011; Thornton, 2014), and has the potential to become a more sustainable livelihood diversification venture if properly harnessed and regulated (Hilson, 2016b). The sector's contribution to national development cannot be underestimated. Given that most ASM activities are locally financed and most of the inputs are locally obtained, their significant contribution to national output showcases the level of financial resources that are injected into ASM communities (ACET, 2017b). As studies have also shown, the sector has served as an escape route for millions of people who seek to avoid the 'agricultural poverty' syndrome (Hilson and Garforth, 2012). In addition, the sector plays a crucial role in rural livelihood diversification strategies (Maconachie and Binns, 2007).

Notwithstanding its economic importance, the sector's compatibility with agriculture continues to be questioned in some quarters due to its destructive mechanisms on agriculture: land degradation and 
farm invasions, water and mercury pollution and the Dutch disease phenomenon. The diffuse nature of alluvial minerals (gold and diamonds) and the inadequate control of their miners partly explain the informal and itinerant nature of small-scale mining (Veiga and Marshall, 2019). Coupled with the reality that the majority of the workers are located in remote areas where law enforcement is virtually non-existent (Wagner, 2016), the widespread and wanton destruction of land, food crops and water bodies are triggered (Boadi et al., 2016). This means the erosion of livelihood opportunities in rural areas where the agrarian economy serves as the prime source of livelihood for most inhabitants. It is worthy of note that after small holder agriculture, ASM is the second highest employer in rural economies, especially in Africa (ACET, 2017b). And studies have shown that in some cases they have complemented each other (Hilson and Garforth, 2013; Maconachie and Binns, 2007; Hilson, 2016b; Kamlongera, 2011; Pijpers, 2014). However the existence of a strong competition between rural farmers and small-scale miners over access to land, labour and water has always negatively impacted agriculture production, the more sustainable of the two industries (agricultural productive lands can be employed to generate alternate crops, on the contrary mineral resources are non-renewable and depletable (Badeeb et al., 2017, p.124)). Land degradation activities by miners reduce the availability of land for agriculture production, with implications for food security, and potential macroeconomic effects through food price inflation; in the long term, this has adverse implications for scale of exports of cash crops and efforts to eradicate hunger (ACET, 2017b). As reported by Boadi et al (2016), the menacing destruction of cocoa farms by illegal miners led to a drop in cocoa production. The land degradation problems associated with ASM also sets in motion a vicious cycle in terms of employment. When mined land is rendered unsuitable for agriculture (Kitula, 2006; Mantey et al., 2016), the loss of employment and income opportunities in the rural agrarian economy lock the local population into ASM, the riskier and more unsustainable of the two ventures (Veiga and Marshall, 2019; Arthur et al., 2016). The agriculture sector becomes multiply hit in the sense that the expansion in the mining sector equates to more environmental externalities like destruction of existing agricultural products (Arthur et al., 2016; Boadi et al., 2016). Not only do these complexities affect agriculture decline, but the propensity of ASM to trap labour to the extractive sector, begins to raise questions about the concept of ASM as a viable livelihood diversification option. In view of this, Aragon and Rud (2012) suggest that in areas where mining occurs close to agricultural productive zones, governmental policy should always consider the impact of mineral-extraction pollution on the agrarian economy and local income. The benefits of mining must be carefully weighed against the environmental costs. 
We however agree with Cartier and Bürge (2011) that the issue is not about mining versus agriculture or replacing one sector with the other. Policy needs to recognise the socio-economic importance of ASM in livelihood diversification strategies. We do not wish to repeat discussions that have been extensively made elsewhere (see for example Hilson, 2016b), but we embrace the idea that employment in farming is good but it does not necessarily fit all labour. Policy will need to recognise that there are 'career farmers', and 'career miners' - 'people who pursue a career within ASM with mineral-led spatial mobility strategies, social mobility aspirations, and collective identity characteristics, whose goal is to become successful miners or businessmen, not to return to agriculture' (Bryceson and Jønsson, 2010). We therefore support the recommendation of Fisher et al. (2019) that in alluvial-mineral rich countries mining regulatory institutions should properly demarcate zones to accommodate both activities as a way of seeking to 'benefit from both their above-and-below-the-ground resources' (Slack, 2013). Where lands are already degraded, options for sustainable remediation should be both researched and given the necessary environmental management policy consideration (e.g., cleaner technologies and phytoremediation, as suggested by Owusu et al. (2019)). In order to enhance policy on livelihood improvement strategies, future research can look more at quantitative analysis of macro and micro-economic impact of small-scale mining externalities on the environment and local incomes. With the recent surge of ASM activities in many resource-endowed countries, such scholarly works would be very useful.

\section{References}

ACET (2017a) African Transformation Report 2017: Agriculture Powering Africa's Economic Transformation. The Arican Center for Economic Transformation.

ACET (2017b) The Impact of Expanding Artisanal and Small-scale Mining on Small Holder Agriculture in West Africa. A Case Study of Burkina Faso, Ghana and Sierra Leone. African Center for Economic Transformation. Ford Foundation.

Afriyie, K. et al. (2016) The good in evil: a discourse analysis of the galamsey industry in Ghana. Oxford Development Studies. 44 (4), 493-508.

Aiken, K. G. (1994) ' Not Long Ago a Smoking Chimney Was a Sign of Prosperity': Corporate and Community Response to Pollution at the Bunker Hill Smelter in Kellogg, Idaho. Environmental History Review. $18(2), 67-86$.

Aizawa, Y. (2016) Artisanal and small-scale mining as an informal safety net: Evidence from Tanzania. Journal of International Development. 28 (7), 1029-1049.

Akabzaa, T. \& Darimani, A. (2001) Impact of mining sector investment in Ghana: A study of the Tarkwa mining region. Third World Network. 
Aragon, F. \& Rud, J. P. (2012) Mining, pollution and agricultural productivity: evidence from Ghana.

Arthur, F. et al. (2016) Nexus between artisanal and small-scale gold mining and livelihood in Prestea mining region, Ghana. Geography Journal. 2016.

Aryee, B. N. et al. (2003) Trends in the small-scale mining of precious minerals in Ghana: a perspective on its environmental impact. Journal of Cleaner production. 11 (2), 131-140.

Auty, R. (1993) Sustaining Development in Mineral Economies: The Resource Curse Thesis. Oxford University Press, New York.

Bach, J. S. (2014) Illegal Chinese gold mining in Amansie West, Ghana-an assessement of its impact and implications. Master's Thesis thesis. Universitet i Agder/University of Agder.

Badeeb, R. A. et al. (2017) The evolution of the natural resource curse thesis: A critical literature survey. Resources Policy. 51,123-134.

Bakia, M. (2014) East Cameroon's artisanal and small-scale mining bonanza: How long will it last? Futures. $62,40-50$.

Banchirigah, S. M. (2008) Challenges with eradicating illegal mining in Ghana: A perspective from the grassroots. Resources policy. 33 (1), 29-38.

Banchirigah, S. M. (2006) How have reforms fuelled the expansion of artisanal mining? Evidence from subSaharan Africa. Resources Policy. 31 (3), 165-171.

Banchirigah, S. M. \& Hilson, G. (2010) De-agrarianization, re-agrarianization and local economic development: Re-orientating livelihoods in African artisanal mining communities. Policy Sciences. $43(2), 157-180$.

Bansah, K. J. et al. (2018) Socioeconomic and environmental assessment of informal artisanal and smallscale mining in Ghana. Journal of Cleaner Production. 202,465-475.

Barrett, C. B. et al. (2001) Nonfarm income diversification and household livelihood strategies in rural Africa: concepts, dynamics, and policy implications. Food policy. 26 (4), 315-331.

Bebbington, A. et al. (2014) Geographies of conflict: Mapping overlaps between extractive industries and agricultural land uses in Ghana and Peru. Oxfam America.

Bebbington, A. \& Williams, M. (2008) Water and mining conflicts in Peru. Mountain Research and Development. 28 (3), 190-196.

Boadi, S. et al. (2016) An analysis of illegal mining on the Offin shelterbelt forest reserve, Ghana: Implications on community livelihood. Journal of Sustainable Mining. 15 (3), 115-119.

Boateng, D. O. et al. (2014) Impact of illegal small scale mining (Galamsey) on cocoa production in Atiwa district of Ghana. Int. J. Adv. Agric. Res. 289-99. 
Bryceson, D. F. (2002) The scramble in Africa: reorienting rural livelihoods. World development. 30 (5), 725-739.

Bryceson, D. F. \& Jønsson, J. B. (2010) Gold digging careers in rural East Africa: Small-scale miners' livelihood choices. World Development. 38 (3), 379-392.

Burrows, E. \& Bird, L. (2017) Gold, guns and China: Ghana's fight to end galamsey. African Arguments. 30.

Cartier, L. E. \& Bürge, M. (2011) Agriculture and artisanal gold mining in Sierra Leone: alternatives or complements? Journal of International Development. 23 (8), 1080-1099.

Chipangura, N. (2019) Towards the decriminalisation of artisanal gold mining in Eastern Zimbabwe. The Extractive Industries and Society. 6 (1), 154-161.

Clifford, M. J. (2011) Pork knocking in the land of many waters: Artisanal and small-scale mining (ASM) in Guyana. Resources Policy. 36 (4), 354-362.

Corden, W. M. (1984) Booming sector and Dutch disease economics: survey and consolidation. oxford economic Papers. 36 (3), 359-380.

Corden, W. M. \& Neary, J. P. (1982) Booming sector and de-industrialisation in a small open economy. The economic journal. 92 (368), 825-848.

Cordy, P. et al. (2011) Mercury contamination from artisanal gold mining in Antioquia, Colombia: The world's highest per capita mercury pollution. Science of the Total Environment. 410,154-160.

Crawford, G. \& Botchwey, G. (2017) Conflict, collusion and corruption in small-scale gold mining: Chinese miners and the state in Ghana. Commonwealth \& Comparative Politics. 55 (4), 444-470.

Cuba, N. et al. (2014) Extractive industries, livelihoods and natural resource competition: Mapping overlapping claims in Peru and Ghana. Applied Geography. 54250-261.

Dai, Q. et al. (2003) 'Mercury contaminations from gold mining using amalgamation technique in Xiaoqinling Region, Shanxi Province, PR China', in Journal de Physique IV (Proceedings). 2003 EDP sciences. pp. 345-348.

Dartey, E. et al. (2013) Urinary arsenic and mercury levels in artisanal miners in some communities in the Obuasi Municipality of Ghana. Journal of Environmental Chemistry and Ecotoxicology. 5 (5), 113118.

Dondeyne, S. \& Ndunguru, E. (2014) Artisanal gold mining and rural development policies in Mozambique: Perspectives for the future. Futures. 62120-127.

Ellis, F. (2006) Agrarian change and rising vulnerability in rural sub-Saharan Africa. New Political Economy. $11(3), 387-397$.

Ellis, F. (1998) Survey article: Household strategies and rural livelihood diversification. The journal of development studies. 35 (1), 1-38. 
Fisher, R. et al. (2019) Artisanal and small-scale mining and rural livelihood diversification: The case of manganese extraction in West Timor, Indonesia. The Extractive Industries and Society. 6 (1), 229240.

Fraser, B. (2016) Peru's gold rush prompts public-health emergency. Nature. 534 (7606), 162-163.

Geenen, S. (2012) A dangerous bet: The challenges of formalizing artisanal mining in the Democratic Republic of Congo. Resources Policy. 37 (3), 322-330.

Geenen, S. (2011) Relations and regulations in local gold trade networks in South Kivu, Democratic Republic of Congo. Journal of Eastern African Studies. 5 (3), 427-446.

Ghose, M. K. \& Roy, S. (2007) Contribution of small-scale mining to employment, development and sustainability-an Indian scenario. Environment, Development and Sustainability. 9 (3), 283.

Graulau, J. (2001) Peasant mining production as a development strategy: the case of women in gold mining The Brazilian Amazon. European Review of Latin American and Caribbean Studies. 71,71104.

Haggblade, S. et al. (2010) The rural non-farm economy: Prospects for growth and poverty reduction. World development. 38 (10), 1429-1441.

Hilson, G. (2002a) An overview of land use conflicts in mining communities. Land use policy. 19 (1), 6573.

Hilson, G. (2016a) Artisanal and small-scale mining and agriculture: Exploring their links in rural subSaharan Africa. IIED, London.

Hilson, G. et al. (2014) Chinese participation in Ghana's informal gold mining economy: Drivers, implications and clarifications. Journal of Rural Studies. 34,292-303.

Hilson, G. (2016b) Farming, small-scale mining and rural livelihoods in Sub-Saharan Africa: A critical overview. The Extractive Industries and Society. 3 (2), 547-563.

Hilson, G. et al. (2019) Formalizing artisanal mining 'spaces' in rural sub-Saharan Africa: The case of Niger. Land use policy. 80,259-268.

Hilson, G. et al. (2013) Going for gold: transitional livelihoods in Northern Ghana. The Journal of Modern African Studies. 51 (1), 109-137.

Hilson, G. (2002b) 'Small-scale mining and its socio-economic impact in developing countries', in Natural Resources Forum. 2002 Wiley Online Library. pp. 3-13.

Hilson, G. (2002c) The environmental impact of small-scale gold mining in Ghana: identifying problems and possible solutions. Geographical Journal. 168 (1), 57-72.

Hilson, G. \& Garforth, C. (2012) 'Agricultural poverty'and the expansion of artisanal mining in Sub-Saharan Africa: experiences from Southwest Mali and Southeast Ghana. Population research and policy review. 31 (3), 435-464. 
Hilson, G. \& Garforth, C. (2013) 'Everyone now is concentrating on the mining': drivers and implications of rural economic transition in the eastern region of Ghana. The Journal of Development Studies. 49 (3), 348-364.

Hilson, G. \& Laing, T. (2017) Guyana Gold: A Unique Resource Curse? The Journal of Development Studies. $53(2), 229-248$.

Hilson, G. \& Pardie, S. (2006) Mercury: An agent of poverty in Ghana's small-scale gold-mining sector? Resources Policy. 31 (2), 106-116.

Hilson, G. \& Potter, C. (2005) Structural adjustment and subsistence industry: artisanal gold mining in Ghana. Development and change. 36 (1), 103-131.

Hilson, G. \& Van Bockstael, S. (2011) Diamond mining, rice farming and a 'maggi cube': a viable survival strategy in rural Liberia? Journal of International Development. 23 (8), 1042-1053.

Humphreys, Macartan et al. (2007) Escaping the resource curse. Columbia University Press.

IGF (2017) Global Trends in Artisanal and Small-Scale Mining (ASM): A review of key numbers and issues. Intergovernmental Forum on Mining, Minerals, Metals and Sustainable Development. Winnipeg: IISD.

Ingram, V. et al. (2011) 'Where artisanal mines and forest meet: Socio-economic and environmental impacts in the Congo Basin', in Natural Resources Forum. 2011 Wiley Online Library. pp. 304-320.

Jacka, J. K. (2018) The Anthropology of Mining: The Social and Environmental Impacts of Resource Extraction in the Mineral Age. Annual Review of Anthropology. 47,61-77.

Kamlongera, P. J. (2011) Making the poor 'poorer'or alleviating poverty? Artisanal mining livelihoods in rural Malawi. Journal of International Development. 23 (8), 1128-1139.

Kinosian, S. (2012) Illegal Mining Contaminates water in Northern Colombia. Colombia Reports. [online]. Available from: https://colombiareports.com/illegal-mining-contaminates-water-in-northerncolombia/.

Kitula, A. G. N. (2006) The environmental and socio-economic impacts of mining on local livelihoods in Tanzania: A case study of Geita District. Journal of cleaner production. 14 (3-4), 405-414.

Kumah, A. (2006) Sustainability and gold mining in the developing world. Journal of Cleaner Production. $14(3-4), 315-323$.

Labonne, B. (2014) Who is afraid of artisanal and small-scale mining (ASM)? The Extractive Industries and Society. 1 (2), 121-123.

Lacerda, L. D. \& Marins, R. V. (1997) Anthropogenic mercury emissions to the atmosphere in Brazil: The impact of gold mining. Journal of Geochemical Exploration. 58 (2-3), 223-229.

Langston, J. D. et al. (2015) Comparative development benefits from small and large scale mines in North Sulawesi, Indonesia. The Extractive Industries and Society. 2 (3), 434-444. 
Lay, J. et al. (2008) Few opportunities, much desperation: The dichotomy of non-agricultural activities and inequality in Western Kenya. World Development. 36 (12), 2713-2732.

Lin, C. et al. (2005) Environmental impacts of surface mining on mined lands, affected streams and agricultural lands in the Dabaoshan mine region, southern China. Land Degradation \& Development. 16 (5), 463-474.

Lindahl, J. (2014) Environmental impacts of mining in Zambia. Towards better environmental management and sustainable exploitation of mineral resources. Geological Survey of Sweden. 27.

Macháček, J. (2019) Typology of Environmental Impacts of Artisanal and Small-Scale Mining in African Great Lakes Region. Sustainability. 11 (11), 3027.

Maconachie, R. (2011) Re-agrarianising livelihoods in post-conflict Sierra Leone? Mineral wealth and rural change in artisanal and small-scale mining communities. Journal of International Development. 23 (8), 1054-1067.

Maconachie, R. \& Binns, T. (2007) 'Farming miners' or 'mining farmers'?: Diamond mining and rural development in post-conflict Sierra Leone. Journal of Rural Studies. 23 (3), 367-380.

Malm, O. (1998) Gold mining as a source of mercury exposure in the Brazilian Amazon. Environmental research. $77(2), 73-78$.

Mantey, J. et al. (2016) Costed reclamation and decommissioning strategy for galamsey operations in 11 selected MDAs of. International Growth Centre.

McQuilken, J. \& Hilson, G. (2016) Artisanal and small-scale gold mining in Ghana: Evidence to inform an "action dialogue." International Institute for Environment and Development.

Mitchell, J. (2016) Pulling the rug out from under: The land tenure dynamics of mining concessions in subSaharan Africa. The Extractive Industries and Society. 3 (4), 1117-1129.

Mkodzongi, G. \& Spiegel, S. (2019) Artisanal gold mining and farming: Livelihood linkages and labour dynamics after land reforms in Zimbabwe. The Journal of Development Studies. 55 (10), 21452161.

MMSD (2002) Breaking New Ground: Mining, Minerals and Sustainable Development. IIED, London.

Mol, J. H. \& Ouboter, P. E. (2004) Downstream effects of erosion from small-scale gold mining on the instream habitat and fish community of a small neotropical rainforest stream. Conservation Biology. 18 (1), 201-214.

Mudyazhezha, S. \& Kanhukamwe, R. (2014) Environmental Monitoring of the Effects of Conventional and Artisanal Gold Mining on Water Quality in Ngwabalozi River, Southern Zimbabwe. International Journal of Engineering. 4 (10), 8269.

Mujere, N. \& Isidro, M. (2016) 'Impacts of artisanal and small-scale gold mining on water quality in mozambique and zimbabwe', in Impact of Water Pollution on Human Health and Environmental Sustainability. IGI Global. pp. 101-119. 
Musemwa, M. (2009) Contestation over Resources: the farmer-miner dispute in colonial Zimbabwe, 19031939. Environment and History. 15 (1), 79-107.

Mwakaje, A. G. (2012) Environmental degradation under artisanal and small-scale mining in Tanzania: can innovations in institutional framework help? Int. J. Environ. Prot. 2 (9), 7-16.

Ncube-Phiri, S. et al. (2015) Artisanal small-scale mining: Potential ecological disaster in Mzingwane District, Zimbabwe. Jàmbá: Journal of Disaster Risk Studies. 7 (1), 1-11.

Ntiamoah, A. \& Afrane, G. (2008) Environmental impacts of cocoa production and processing in Ghana: life cycle assessment approach. Journal of Cleaner Production. 16 (16), 1735-1740.

Nunez, C. (2019) Deforestation explained. National Geographic. [online]. Available from: https://www.nationalgeographic.com/environment/global-warming/deforestation/ (Accessed 24 September 2019).

Nyame, F. K. \& Blocher, J. (2010) Influence of land tenure practices on artisanal mining activity in Ghana. Resources Policy. 35 (1), 47-53.

Obiri, S. et al. (2016) Assessing the environmental and socio-economic impacts of artisanal gold mining on the livelihoods of communities in the Tarkwa Nsuaem municipality in Ghana. International journal of environmental research and public health. 13 (2), 160.

O'Faircheallaigh, C. \& Corbett, T. (2016) Understanding and improving policy and regulatory responses to artisanal and small scale mining. The Extractive Industries and Society. 3 (4), 961-971.

Ogola, J. S. et al. (2002) Impact of gold mining on the environment and human health: a case study in the Migori gold belt, Kenya. Environmental geochemistry and health. 24 (2), 141-157.

Okoh, G. \& Hilson, G. (2011) Poverty and livelihood diversification: Exploring the linkages between smallholder farming and artisanal mining in rural Ghana. Journal of International Development. 23 (8), 1100-1114.

Owusu, O. et al. (2019) 'Small in size, but big in impact': Socio-environmental reforms for sustainable artisanal and small-scale mining. Journal of Sustainable Mining.

Owusu-Nimo, F. et al. (2018) Spatial distribution patterns of illegal artisanal small scale gold mining (Galamsey) operations in Ghana: A focus on the Western Region. Heliyon. 4 (2), e00534.

Patel, K. et al. (2016) Evaluating conflict surrounding mineral extraction in Ghana: assessing the spatial interactions of large and small-scale mining. The Extractive Industries and Society. 3 (2), 450-463.

Peck, P. \& Sinding, K. (2003) Environmental and social disclosure and data richness in the mining industry. Business Strategy and the Environment. 12 (3), 131-146.

Persaud, A. W. et al. (2017) Artisanal and small-scale gold mining in Senegal: livelihoods, customary authority, and formalization. Society \& natural resources. 30 (8), 980-993. 
Peterson, G. D. \& Heemskerk, M. (2001) Deforestation and forest regeneration following small-scale gold mining in the Amazon: the case of Suriname. Environmental Conservation. 28 (2), 117-126.

Petticrew, M. \& Roberts, H. (2006) Systematic reviews in the social sciences: A practical guide. Blackwell Publishers, Malden, Massachusets, USA.

Pfeiffer, W. C. et al. (1993) Environmental fate of mercury from gold mining in the Brazilian Amazon. Environmental Reviews. 1 (1), 26-37.

Pijpers, R. (2014) Crops and carats: Exploring the interconnectedness of mining and agriculture in SubSaharan Africa. Futures. 62,32-39.

Reardon, T. et al. (1994) Links between nonfarm income and farm investment in African households: adding the capital market perspective. American journal of agricultural economics. 76 (5), 11721176.

Reardon, T. et al. (2001) Rural nonfarm employment and incomes in Latin America: overview and policy implications. World development. 29 (3), 395-409.

Ross, M. L. (2003) Oil, Drugs and Diamonds: The Varying Role of Natural Resources in Civil War.

Ross, M. L. (2004) What do we know about natural resources and civil war? Journal of Peace Research. 41 (3), 337-356.

Ross, M. L. (2015) What Have We Learned about the Resource Curse? Annu. Rev. Polit. Sci. 18,239-59.

Sachs, J. D. (2007) How to handle the macroeconomics of oil wealth. M. Humphreys, J. Sachs, J.Stiglitz (Eds.), Chapter 7 in Escaping the Resource Curse, Columbia University Press, NY (2007), pp. 173193.

Sachs, J. D. \& Warner, A. M. (1995) Natural Resource Abundance and Economic Growth.

Salo, M. et al. (2016) Local perspectives on the formalization of artisanal and small-scale mining in the Madre de Dios gold fields, Peru. The Extractive Industries and Society. 3 (4), 1058-1066.

Savo, V. et al. (2016) Observations of climate change among subsistence-oriented communities around the world. Nature Climate Change. 6 (5), 462.

Schueler, V. et al. (2011) Impacts of surface gold mining on land use systems in Western Ghana. Ambio. 40 (5), 528-539.

Seccatore, J. et al. (2014) An estimation of the artisanal small-scale production of gold in the world. Science of the Total Environment. 496,662-667.

Serfor-Armah, Y. et al. (2005) The impact of small-scale mining activities on the levels of mercury in the environment: The case of Prestea and its environs. Journal of Radioanalytical and Nuclear Chemistry. 262 (3), 685-690. 
Shoko, D., SM (2002) Small-scale mining and alluvial gold panning within the Zambezi Basin: an ecological time bomb and tinderbox for future conflicts among riparian states. Managing Common Property in an Age of Globalisation: Zimbabwean Experiences. 67,85.

Siegel, S. \& Veiga, M. M. (2010) The myth of alternative livelihoods: artisanal mining, gold and poverty. International Journal of Environment and Pollution. 41 (3-4), 272-288.

Siwale, A. \& Siwale, T. (2017) Has the promise of formalizing artisanal and small-scale mining (ASM) failed? The case of Zambia. The Extractive Industries and Society. 4 (1), 191-201.

Slack, K. (2013) The growing battle between mining and agriculture. Oxfam. [online]. Available from: https://politicsofpoverty.oxfamamerica.org/2013/04/the-growing-battle-between-mining-andagriculture/ (Accessed 19 September 2019).

Teschner, B. A. (2014) "Orpaillage pays for everything": How artisanal mining supported rural institutions following Mali's coup d'état. Futures. 62140-150.

Teschner, B. A. (2012) Small-scale mining in Ghana: The government and the galamsey. Resources Policy. [Online] 37 (3), 308-314.

The World Bank (2019) Agriculture and Food: overview - context. [online]. Available from: https://www.worldbank.org/en/topic/agriculture/overview (Accessed 15 September 2019).

Thornton, R. (2014) Zamazama, "illegal” artisanal miners, misrepresented by the South African Press and Government. The Extractive Industries and Society. 1 (2), 127-129.

Tom-Dery, D. et al. (2012) Effect of illegal small-scale mining operations on vegetation cover of arid northern Ghana. Research journal of environmental and earth sciences. 4 (6), 674-679.

Tschakert, P. (2009) Recognizing and nurturing artisanal mining as a viable livelihood. Resources Policy. 34 (1-2), 24-31.

Van Bockstael, S. (2014) The persistence of informality: Perspectives on the future of artisanal mining in Liberia. Futures. 62,10-20.

Van Straaten, P. (2000) Mercury contamination associated with small-scale gold mining in Tanzania and Zimbabwe. Science of the Total Environment. 259 (1-3), 105-113.

Veiga, M. M. \& Marshall, B. G. (2019) The Colombian artisanal mining sector: Formalization is a heavy burden. The Extractive Industries and Society. 6 (1), 223-228.

Verbrugge, B. (2014) Capital interests: A historical analysis of the transformation of small-scale gold mining in Compostela Valley province, Southern Philippines. The Extractive Industries and Society. $1(1), 86-95$.

Verbrugge, B. (2016) Voices from below: artisanal-and small-scale mining as a product and catalyst of rural transformation. Journal of rural studies. 47108-116.

Wagner, L. (2016) Organized Crime and Illegally Mined Gold in Latin America. Global Initiative. 
Walsh, A. (2003) ' Hot money' and daring consumption in a northern Malagasy sapphire-mining town. American Ethnologist. 30 (2), 290-305.

Weber-Fahr, M. (2002) Treasure or trouble? Mining in developing countries. World Bank and International Finance Corporation, Washington DC.

Webster, J. \& Watson, R. T. (2002) Analyzing the past to prepare for the future: Writing a literature review. MIS quarterly. 26 (2), xiii-xxiii.

Werthmann, K. (2003) Cowries, gold and 'bitter money'. Gold-mining and notions of ill-gotten wealth in Burkina Faso. Paideuma. 49105-124.

\section{Figure 1: ASM-agriculture complementarities cycle}

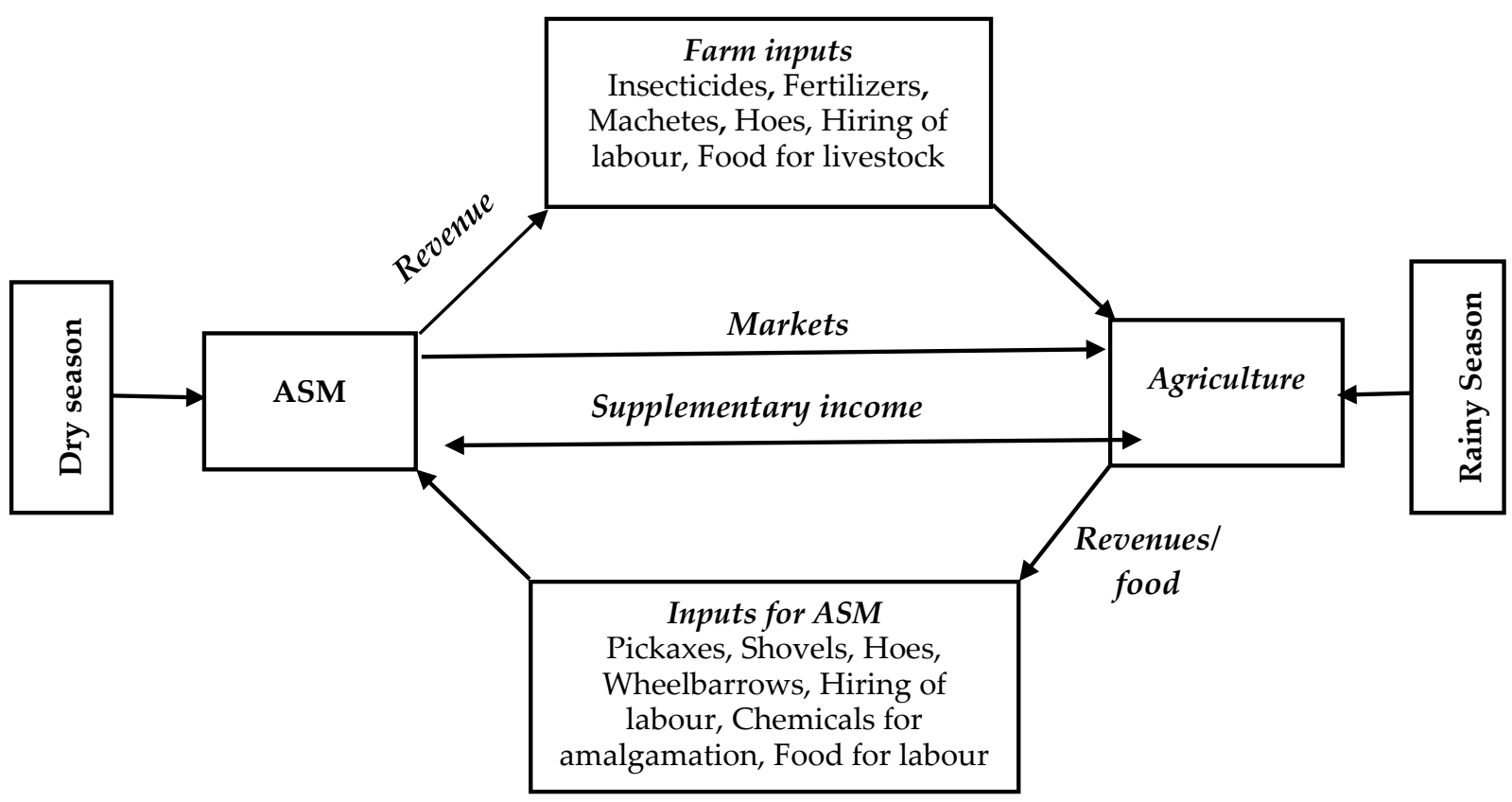

Figure 2: Summary of ASM-agriculture collision course

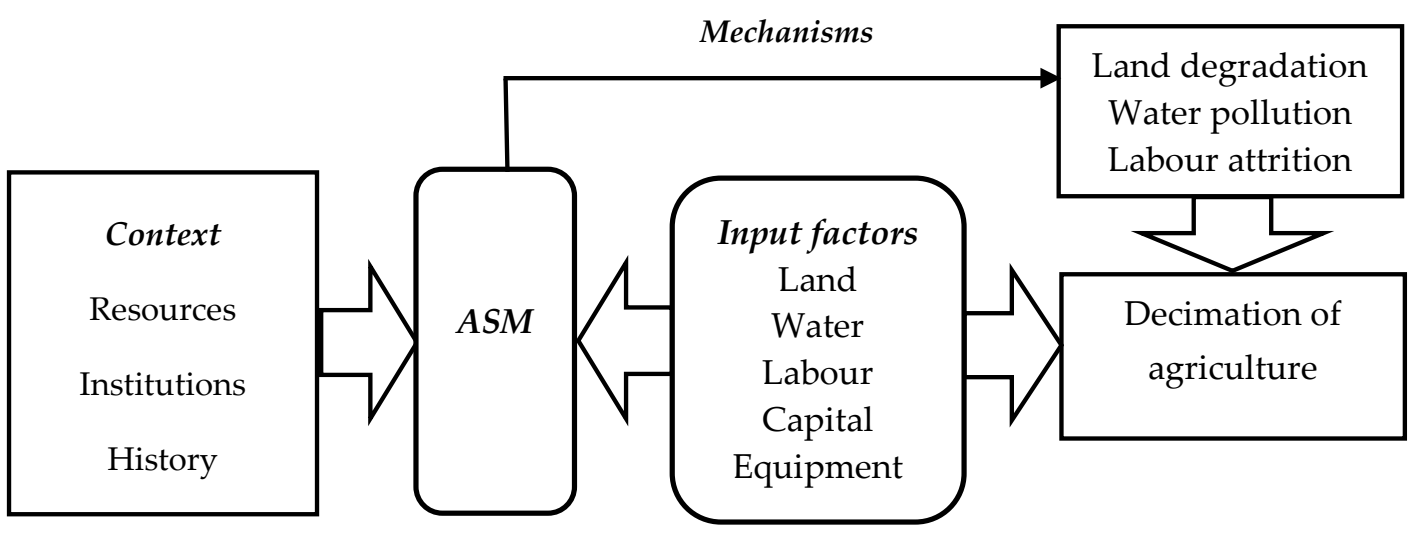




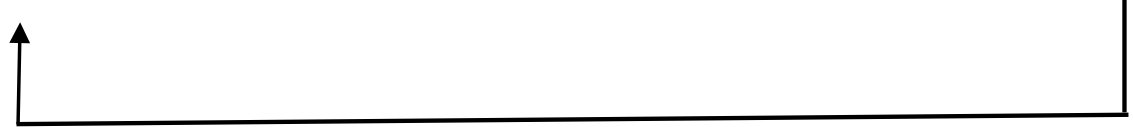



Table 1: Key works on ASM-agriculture interface

\begin{tabular}{|c|c|c|c|}
\hline Study & Mineral/Country(ies) & Category & Key recommendation(s) \\
\hline Fisher et al., (2019) & (Manganese)/Indonesia & Positive & $\begin{array}{l}\text { More engagement between levels of government with regard to ASM licensing } \\
\text { procedures and demarcation of mineralised lands }\end{array}$ \\
\hline $\begin{array}{l}\text { Mkodzongi and } \\
\text { Spiegel (2018) }\end{array}$ & (Gold)/Zimbabwe & Positive & $\begin{array}{l}\text { Academics and policy makers would need to recognise and streamline ASM because it } \\
\text { is a vital source of income }\end{array}$ \\
\hline $\begin{array}{l}\text { Hilson and Laing } \\
\text { (2017) }\end{array}$ & (Gold)/Guyana & Negative & $\begin{array}{l}\text { Mineral revenues need to be reinvested in other sectors of the economy including } \\
\text { agriculture for the purposes of economic diversification }\end{array}$ \\
\hline Arthur et al. (2016) & (Gold)/Ghana & Negative & $\begin{array}{l}\text { Land policy should include land reclamation and refill and reforestation programmes. } \\
\text { Buffer zones should be created to prevent ASM activities in water bodies. }\end{array}$ \\
\hline Boadi et al. (2016) & (Gold)/Ghana & Negative & A holistic and multifaceted approach to tackle illegal ASM \\
\hline $\begin{array}{l}\text { Ncube-Phiri et al. } \\
\text { (2015) }\end{array}$ & (Gold) Zimbabwe & Negative & $\begin{array}{l}\text { Regularisation and formalisation of ASM through licensing in order to raise taxes for } \\
\text { remediation. Emphasis on the need for intensified environmental education and } \\
\text { awareness }\end{array}$ \\
\hline Pijpers (2014) & $\begin{array}{l}\text { (Gold and } \\
\text { diamonds)/Sierra Leone, } \\
\text { Ghana, South Africa }\end{array}$ & Positive & $\begin{array}{l}\text { ASM and agriculture sectors should be developed and professionalise to contribute to } \\
\text { an increase in sustainable opportunities }\end{array}$ \\
\hline $\begin{array}{l}\text { Hilson and Garforth } \\
\text { (2013) }\end{array}$ & (Gold)/Ghana & Positive & $\begin{array}{l}\text { Nuanced and positive policy stance towards ASM and its interactions with smallholder } \\
\text { agriculture }\end{array}$ \\
\hline $\begin{array}{l}\text { Hilson and Van } \\
\text { Bockstael(2012) }\end{array}$ & (Diamonds)/Liberia & Positive & $\begin{array}{l}\text { Government should provide support for rural livelihood diversification strategies } \\
\text { including ASM }\end{array}$ \\
\hline $\begin{array}{l}\text { Hilson and Garforth } \\
\text { (2012) }\end{array}$ & (Gold)/Ghana, Mali & Positive & ASM should be supported and integrated into rural development strategies \\
\hline Kamlongera (2011) & $\begin{array}{l}\text { Gemstone (blue } \\
\text { agate)/Malawi }\end{array}$ & Positive & Formalisation of ASM. More geological data must be collected and made available \\
\hline $\begin{array}{l}\text { Okoh and Hilson } \\
\text { (2011) }\end{array}$ & (Gold)/Ghana & Positive & Regularisation of ASM as a way of providing security of tenure for miners. \\
\hline $\begin{array}{l}\text { Cartier and Bürge } \\
\text { (2011) }\end{array}$ & $\begin{array}{l}\text { (Gold and } \\
\text { diamonds)/Sierra Leone }\end{array}$ & Positive & ASM formalisation and investment in local mining production and trading channels \\
\hline
\end{tabular}


Maconachie (2011)

Maconachie and Binns

(2007)

Kitula (2006)
(Gold and

diamonds)/Sierra Leone

(Diamonds)/Sierra Leone

(Gold)/Tanzania
Positive

Positive

Negative
Policy should recognise and give more support to the links between ASM and agriculture

Policy should ensure that ASM is undertaken in an environmentally sustainable manner

Policy should strategies in eliminating illegal ASM and to promote income-generating activities like agriculture to help improve the social, economic, and environmental management of natural resources 